\title{
Helleborus sp. an ethnopharmacological and toxicological review
}

\author{
Andzela Brajanovska, Biljana Bauer \\ Faculty of Pharmacy, Ss. Cyril and Methodius University, Majka Tereza 47, \\ 1000 Skopje, Republic of Macedonia
}

Received: September 2018; Accepted: November 2018

\begin{abstract}
Helleborus sp. are healing plants from the family Ranunculaceae. The aim of this paper is to consider ethnopharmacology and the toxicity of the hellebores which is focused on a detailed research of the value of phytochemicals, as pharmacological attributes of phytomedicine herbs. The data is based on active components. Also, this paper presents the chemical composition of the root in the overall effect of the drug, as well as the importance of the hellebores in pharmacy. It shows a wide range of pharmacological effects such as cardiotonic, immunostimulative, antibacterial, antitumor, diuretic, and emetic. Helleborus odorus Waldst. et Kit. is rich with secondary metabolites such as bufadenolides, flavonoids, phenolic heterozids. With this research it was concluded that these plants have great significance and great application in the formulation of pharmaceutical dosage forms.
\end{abstract}

Keywords: Helleborus sp., phytomedicine, folk medicinal uses, cardiotonic, toxicity, hellebore

\section{Introduction}

Medicinal herbs have been used for healing from the beginning of the historical development of mankind. When primal people were suffering from some disease, they were directed to nature, seeking help from it. Surrounded by herbs, insects, animals, and hunted by the self-preservation instinct, people used them to fight the disease. Personal, or following the general and animal samples, people made a selection of herbs, although they often paid for it with life. Numerous literary data indicate the early application of hellebores in traditional folk medicine.

Helleborus sp. and its use began in old civilizations, more than $2500 \mathrm{BC}$, when ancient Greeks used Helleborus niger L. (Helleboros melas) because of his own strong diuretic, emetic and narcotic effects, which cures deafness, leprosy, scabies and psychological disorders (Vitalini et al., 2011). This species today dominates the flora of Southern and Eastern Europe. Orators in ancient Greece used infusions prepared from the leaves of Helleborus cyclophyllus Boiss. which strengthened their voice. The old people used hellebores to spread their arrows either when they went on hunting or in wars (Tucakov, 1996). Hippocrates (459-377 BC) and Theophrastus (370-287 BC) have data on the functioning of the hellebores at constipation as laxative and emetic. The Roman medical writer Celsius (25 BC to 50 BCE) in the book "De re medica" and physician Galen recorded the medicinal effect of the hellebores in reducing pain (besides cannabis, opium), causing sneezing, in mental disorders (psychosis and depression) and epilepsy. The Romans made a diuretic beverage from this plant that helped to remove the toxins from the body (Van Tellingen, 2007).

\footnotetext{
* biba@ff.ukim.edu.mk
} 
In the Italian folk medicine, underground parts of hellebores in the shape of decoct as a cardiotonic agent and as a remedy for the purpose of improving the digestive tract was used (Coassini and Poldini, 1988). Alcohol extract from the stem, rhizome and root acts directly in the treatment of migraine, and is also used as an anabolic, vasodilator and antiseptic medicine (Tosevski, 1999). Dried rhizome from Helleborus thibetanus Franch. Is used in folk medicine for the treatment of cysts and traumatic injuries (Yang et al., 2010).

Regardless of religion and social order, all nations in the world have, in a greater or lesser extent, usage of hellebores for healing of various diseases. In this paper, the action, as well as the active components of the hellebore, Helleborus odorus Waldst. et Kit. (Syn.: H. cyclophyllus Boiss.), a herb of the family Ranunculaceae, has been taken in considerations, because it can also be a drug or poison for the heart.

\section{Taxonomy}

According to the current scientific systematics of the herbarium, the taxonomic species Helleborus odorus Waldst. et Kit. Is from the kingdom (Regnum) Plantae s. Vegetabilia (most herbs Cormobionta), division Magnoliophyta s. Angiospermae (flowers Anthopyta), classis dicotyledone Magnoliopsida s. Dicotyledones, ordo Ranunculales s. Ranales, familia Ranunculaceae, subfamilia Ranunculoideae, genus Helleborus L., subgenus Helleborastum (Gajić, 1992).

Hellebores are found in the forests or beside them and along the pastures up to 1500 meters, very often throughout Republic of Macedonia. Many authors have cited Helleborus cyclophyllus Boiss. From Macedonia as a special species (Micevski, 1985).

\section{Phytochemistry}

Early in the $19^{\text {th }}$ century many researchers began researching the chemical structure and the effects of many different plant species. First detailed paper on the chemical structure of the genus Helleborus L., of the identification, isolation, characteristics and the biological activity of certain ingredients was done by Husemann and Marmé in 1865. Modern analytical methods have made possible to isolate and thoroughly investigate the structure, biogenesis and the role of various ingredients of the hellebores, but this primary and secondary metabolites, has not yet been sufficiently studied on the human organism.

\section{Primary metabolites in the genus Helleborus $\mathbf{L}$.}

Many authors, beside the pharmacologically active substances from the underground organs of the hellebores, also examined the content of the primary metabolites. Glucose and other carbohydrates occur by photosynthesis process, transformation and polymerization, as well as with glycolysis, there is the formation of fatty acids and lipids, amino acids and peptides.

\section{Carbohydrates}

Carbohydrates are universal ingredients of all living organisms and represent the energy source for the cells. In the plant tissue have a material role, they are integral parts metabolites and precursors of secondary metabolites (Kovacević, 2000). The biochemical Bourquelot method of enzymatic hydrolysis of heterosides was performed on previously stabilized rhizomes and roots of Helleborus odorus Waldst. et Kit. And Helleborus atrorubens Waldst. et Kit. (Stefanović, 1962). For hydrolysis, the follow enzymes were used: invertin (acting on $\alpha$-glucosides) and emulsine (acting on $\gamma$-glucosides). By comparing of the optical activity of the 4emperature and the amount of reductive substances before and after hydrolysis and the calculated enzymolytic reduction index, it was noted that in the underground organs of Helleborus odorus Waldst. et Kit. Besides sucrose, there are both raffinose and starchy or one of them, and in Helleborus atrorubens Waldst. et Kit. There is only saccharose. Enzyme preparation obtained from the leaves and from the underground hellebores organs gave negative results. Stefanovic (1962) from 96\% alcoholic extract of underground organ of hellebores, by chromatography method on the column of aluminum oxide (Merck) isolate sucrose, thereby was confirmed her presence in the underground organs of Helleborus odorus Waldst. et Kit. (in small quantities) and in Helleborus atrorubens Waldst. et Kit.(3\%), which was previously been determined only by a biochemical method. Then, by chromatography on paper at Helleborus odorus Waldst. et Kit. Were identified: raffinose, sucrose, galactose, glucose, fructose, and at Helleborus atrorubens Waldst. et Kit. In addition to the above, also lyxose was present. Baytop and Malkoc, 1965 in the infusions and tinctures of underground organs of Helleborus orientalis Lam. Find glucose, fructose and sucrose (Bottcher, 1965).

\section{Lipid materials}

Fatty substances represent the energy reserve of plant cells, and their quantity is not a type of species, but depends on the conditions of the environment (temperature, humidity, mineral matter, soil) and stages of plant development. Most of the oil of the underground organs of the hellebores comprised the widespread classes of lipid substances: phospholipids, mono-, di- and triglycerides, free fatty acids and non-fatty moieties (sterols, esterified sterol derivatives and hydrocarbons in an amount of $0.03-1.5 \%$ ). They are in the root and rhizomes accumulated in large quantities (14-18\%), which 
is a rare occurrence in the plant world. In the fatty oils of the underground organs and seeds in the genus Helleborus L. the most frequent are the triglyceride fractions and free fatty acids, where the dominance of unsaturated fatty acids is an important feature of lipid biosynthesis in plants of this gender. By qualitative and quantitative analysis of the content of oils matter in the underground organs of Helleborus atrorubens Waldst. et Kit. Was found that its content in rhizome and root does not qualitatively distinguish, but rhizome $(11.12 \%)$ is richer in greasy ingredients than the root $(8.08 \%)$ (Čučković, 1939).

The content of fatty substances from the rhizome and roots of Helleborus odorus Waldst. et Kit. Was examined and a higher amount of oil from the root, than from rhizome was obtained, for each month during the vegetation period (Živanov-Stakić and Mladenović, 1971). Minimum amount of fat in both of the underground organs was in December, rising in January, February and March. The highest value reached in April when leaves are formed, it falls in June when the fruit mature, and from August to November there is a slight increase. In the isolated oil the refractive index, acidic, saponification, ester and iodine number has been determined and the ratio of free, esterified and unsaturated fatty acids was obtained during the growing period. The content of the non-saponified part is determined with gravimetric method. The lowest value was determined in December $(1.1 \%)$, and the highest in April (5.6\%), while with chromatography on a thin layer $\beta$-sitosterol, other free and esterified phytosterols were determined. Serebryakov, 1982 and Anguladze, 1983 found that lipids of the rhizome and roots of Helleborus abchasicus A. Braun and Helleborus caucasicus A. Braun were characterized with high content of free fatty acids (about $70 \%$ ) in the period of flowering, where linoleic acid $(82.6 \%)$ is dominant, and the presence of $\beta$-sitosterol has been demonstrated. Oxidation of lipids from the underground organs of Helleborus caucasicus A. Braun is going in the direction of creation of keto acids and free fatty acids (Dalakishvili, 1983). Variations in the content of fatty substances and fatty acids in the underground organisms of the genus Helleborus L. was examined during the ontogenetic development over two years. Colombo, 1991 has found that the amount of fat in Helleborus odorus Waldst. et Kit. And Helleborus viridis L. is highest during the rest period (since October until February) characterized by relatively high metabolic activity and small growth, the smallest in the spring when the plant uses lipid growth reserves. In Helleborus niger L. higher temperatures have a positive effect on the synthesis and accumulation of lipids, so there is the largest amount in the period of growth and development (maximum in July). The content of fatty substances during the entire vegetation period was higher in 5empera of Helleborus odorus Waldst. et Kit. And in Helleborus viridis L., and at Helleborus niger L. in root.

\section{Amino acids and peptides}

The amino acids in the cells and tissues of the plants are free or in oligopeptides and proteins, and enter into the composition of some groups of secondary metabolites (alkaloids, sulfur and cyanogenic heterozyme) (Kovacevic, 2000). The method of two-dimensional chromatography on paper, (Stefanović, 1962), on an alcohol extract from the underground parts of Helleborus odorus Waldst. et Kit. Identifies and separates the follow amino acids: asparagine, aspartic and glutamic acid, serine, lysine, arginine, glycine, histidine, threonine, alanine, proline, methionine, valine, leucine and isoleucine, while in the extract from Helleborus atrorubens Waldst. et Kit. Not detect amino acid serine.

Milbradt et al. (2003) from the rhizome of Helleborus purpurascens Waldst. et Kit. Isolated cystine peptide heletionin D, potentially useful in tumor therapy. They found the antimicrobial activity and the cytotoxic effect of helethionin D, based on its binding to cell phospholipids causing lysis and cell death. It is possible to produce transgenic plants containing thionine genes responsible for increasing resistance to pathogenic microorganisms, fungi and yeast; while on the other hand, hellebores can be used as antitumor support therapy (Grossarth-Maticek et al., 2001).

Pěnćík (2009) has developed a highly specific analytical protocol for isolation and quantification of indole-3-acetic acid (IAA), which is important for the 5emperature 5 auxin, and its amino acid conjugates having a storage function or degradation of excessive IAA. By combining of anti-IAA immunoaffinity extraction with sensitive and selective LC-MS / MS analysis, with the application of internal standards, in a small amount of unripe seeds (about $30 \mathrm{mg}$ ) of Hellebous niger L. the physiological levels of these compounds were found in a range of $7.5 \mathrm{nmol} / \mathrm{g}$ of IAA to $0.44 \mathrm{pmol} / \mathrm{g}$ of IAA conjugated to alanine. IAA level and it is conjugates with Asp, Glu and Leu in the pericarp were significantly lower than those in the seed, while the conjugates with Ala, Gly, Phe and Val were below the limits of detection.

\section{Secondary metabolites of the genus Helleborus $\mathbf{L}$.}

Secondary metabolites are specific, biologically active ingredients that have therapeutic use. Secondary metabolites are due to the metabolic processes of primary metabolites associated with catabolism and/or transformation of carbohydrate, amino acid or fatty acid molecules.

The first analyze of the chemical composition of different species of Helleborus was in 1808 year in alcoholic extract of Helleborus hiemalis L. (Eranthis hiemalis Salisb.), when the resin a substance called 
heleborin was isolated (Dilparić-Knežević, 1977). Bastik forty-five years later (1853) from Helleborus niger L. isolated heleborin in crystal form. The same author points out that Marmé in the middle of the $19^{\text {th }}$ century (1864) from the rhizome and root of Helleborus niger $\mathrm{L}$. managed to isolate heleborin, soluble in alcohol and chloroform, and also isolates the new substance heleborein, which was easily soluble in water, hard in alcohol and insoluble in the ether. With drying and evaporating of the aqueous solution transparent yellow resin was obtained. A year later, Husemann and Marmé (1865) published the results of the chemical analyzes of both substances isolated from the underground organs from Helleborus niger L., Helleborus viridis L. and Helleborus foetidus $\mathrm{L}$. which point out on their glycosidic nature. Heleborin $\left(\mathrm{C}_{36} \mathrm{H}_{42} \mathrm{O}_{6}\right)$ by hydrolysis was splited to aglycol helebororesin $\left(\mathrm{C}_{30} \mathrm{H}_{38} \mathrm{O}_{4}\right)$ and one glucose molecule, and heleborein $\left(\mathrm{C}_{26} \mathrm{H}_{44} \mathrm{O}_{15}\right)$ to aglycone heleborethine $\left(\mathrm{C}_{14} \mathrm{H}_{20} \mathrm{O}_{3}\right)$ and two glucose molecules. They found that heleborin demonstrated narcotic and hemolytic action and is supposed that by composition it was saponin, while heleborein exhibited cardiac function similar to that of digitalis.

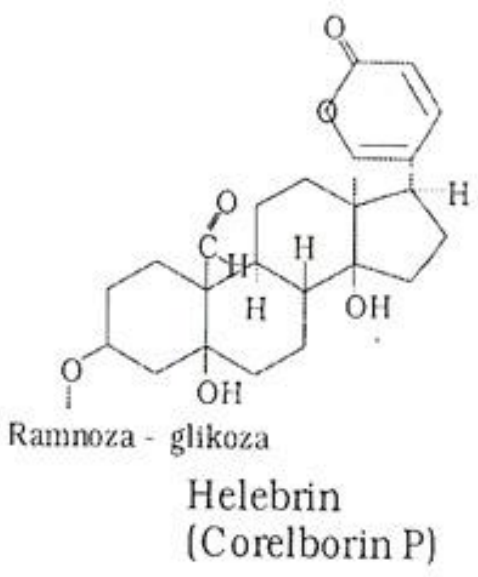

Fig. 1. Helebrin

Helebrin (Fig. 1) (Karrer, 1943) is the first isolated compound of many others from the underground parts of Helleborus niger L. from different habitats in Switzerland, Germany, France, Austria, Hungary and Romania. By extraction with Soxhlet, 6emperatu $\left(\mathrm{C}_{36} \mathrm{H}_{52} \mathrm{O}_{15}\right)$ was isolated as the only substance with glycosidic character (6emperature6n - glukoraminoside). It is believed that 6emperatu is the major cardiac compound of the genus Helleborus L. Helebrin is separated in the form of colorless non - hygroscopic crystal, which in water and ethyl alcohol is difficult to dissolve (about 0.45 or $0.2 \%$ ), slightly easier in methyl alcohol (about 0.6\% - 0.7\%), even more easily in dilute methyl and ethyl alcohol, and insoluble in chloroform and ether. Helebrin is physiologically very active: $1 \mathrm{~g}$ of 6emperatu contains
$25 \times 10^{5}-32 \times 10^{5}$ F.D (Frosch-Dosisrogs doses), while the effectiveness is strongest of the cardioactive glycosides convalatoxin $30 \times 10^{5}-35 \times 10^{5}$ F.D./g. Lethal dose of 6emperatu for adult cats at intravenous administration is $0.1 \mathrm{mg} / \mathrm{kg}$. Oral administration of $1 \mathrm{mg}$ is without symptoms, while a $10 \mathrm{mg}$ dose gives a lethal outcome. Comparing these values with the values for heleborein, Karrer (1943) came to the conclusion that 6emperatu is 20-30 times more effective than heleborein (i.v. heleborein LD $1.9 \mathrm{mg} / \mathrm{kg}$, 6emperatu LD $0.1 \mathrm{mg} / \mathrm{kg}$; heleborein LD $300 \mathrm{mg}$, 6emperatu LD $10 \mathrm{mg}$ ). Shmuz determines the structure of this glycoside, by using a strofantobiasis to separate D-glucose from helibrine. Monoside desglucohelebrine was obtained which was further hydrolyzed by diluted hydrochloric acids in acetone to L-rhamnose and highly active helebrigine (Steinergger, 1972).

\section{Pharmacological activity}

Depending on the conditions (doses, application modes), the total extract as well as individual fractions of rhizomes and roots of the hellebores, exhibit multiple bioactive effects and can act in several directions. The mechanisms of action in most cases are not sufficiently precisely examined and described or unknown. Identification and characterization of Helleborus L. extract components involved in the induction of certain effects are of primary importance for clarifying the basic mechanisms of their in vitro and in vivo activity.

\section{Immunositmulative effect}

In animal health care, immunomodulatory substances are used, which by different mechanisms, change the level of activity of the components of the immune system. Exogenous immunomodulators stimulate the immune response of the cellular and humoral type (immunostimulators) or reduce unwanted effects of the immune system activity and they encourage mechanisms of tolerance in order to reduce the negative response to their own and allo-antigens (immunosuppressants prevent transplant rejection, allergic and autoimmune reactions). A large number of substances have been identified with immunomodulatory substances from chemical products to products of plant origin, and it is confirmed that the extract of rhizomes and the root of the hellebores acts immunomodulatory (Rosselli et al., 2007).

\section{Cardiotonic effect}

Glycosides from Helleborus odorus Waldst. et Kit. Have a expressive cardiovascular effect. The effect is somewhat more expensive than that of the digitalis, and 
worse than the strophant and less accumulates from the digitalis glycosides. Heleborin is the main active substance in the Helleborus odorus Waldst. et Kit. And is the carrier of cardiovascular effect. Heleborein is more effective than k-strophabrizide in intravenous administration, but it is very toxic: the lethal dose (LD) of $\mathrm{k}$-strophantozide is $0.260 \mathrm{mg} / \mathrm{kg}$, while of heleborin is $0.176 \mathrm{mg} / \mathrm{kg}$. Helleborus odorus Waldst. et Kit. Have a lot of applications in veterinary medicine. It is prepared as decoct as antiparasitic medicine and as a purgative (Rosselli et al., 2007). In contact with skin and mucous membranes, Helleborus odorus Waldst. et Kit. Manifest a very irritating effect, followed by burning and redness, and rarely dermatitis.

\section{Antibacterical effect}

Rosselli and coworkers, 2007 analyzed the antibacterical action of the extract of Helleborus bocconei ssp. Intermedius, and established that it acts inhibitory to Staphylococcus epidermalis and Staphylococcus aureus. Root of Helleborus bocconei Ten. Ssp. Siculus contains substances with antibacterial activity, so is justified the usage of this herb in traditional treatment to treat respiratory diseases (Puglisi et al., 2009).

\section{Toxical effect}

A large number of plant species (more than 1000) contain components which interfere with the metabolism, or have a direct or indirect toxic effect. However, only a small group of these plants leads to severe poisoning after the introduction of a limited amount of plant material, while most cause poisoning only under certain circumstances (Frohne and Pfänder, 2005).

"Third Defense", work of the Paracelsus (1493-1541) points out: "What is not poison? All things are poison and nothing is not poisonous. The dose only makes the thing a poison" (Deichmann and al., 1986). A well-known principle "Dosis sola facit venenum" is equally important for the toxic as well as for medicinal plants; because it indicates that the degree of toxicity of a particular plant species depends on the dose entered in organism (Mulet, 1991). Toxicity of hellebores depends on the degree of maturity or phenophase (leaf, flowering, fruiting), from plant organism (accumulation of toxic substances takes place in the leaf, fruits, seeds or underground organs) and whether it is used fresh or dried (Spoerke and Smolinske, 1990).

Pre-conditions for poisoning are: contact with the plant, a high enough dose of toxic ingredients to exhibit activity in or on body and defensive defense mechanisms and detoxification processes of the organism. Level poisoning of animals depends on the type of animal, nutrition, health status, age and pregnancy. Young, poorly-nourished and gravid animals are more likely to get sick and more severe clinical form of the poisoning (Frohne and Pfänder, 2005).

In phytotherapy the term "toxicity or toxic plants" can be conditionally used, since many of them are used as medicines in traditional and conventional medicine, sometimes as an antidote. New findings suggest that the hellebores take a significant place in systematic therapy, which is consulted with alternative medicine labeled as homeopathy. Its application stimulates mental and physiological functions in neurological and mental regression, and is also indicated in septicemia, autism, learning difficulties and act in psychosis in young women.

It is thought that Alexander the Great, died as a result of poisoning with this hellebore with which was spicy up the wine he drank (Deichmann, 1986). From previous investigations that were made, it was concluded that the hellebores could also be a poison and a medicine for the heart, because it contains bufadenylid heterozids, which in small therapeutic doses act toxic to the heart (cardiotonic), but because of its low therapeutic width, it can act cardiotonic.

\section{Conclusion}

Helleborus sp. Are a medical plants originating from the Ranunculaceae family that attracted researchers for its traditional medicinal uses and highly valued bioactive substances. Through this paper, the systematics of the hellebores, as well as the chemical composition, the action and the use of these plants are considered. Because of their toxicity, these plants are strictly limited in medicine as well as for folk purposes because they contain bufadenylid heterozids, which in small therapeutic doses act toxic to the heart (cardiotonic) similar to the digitalis, which this herbs placed in the group of poisonous plants. The medicinal and toxic properties of these plants originate from the secondary metabolites that are biochemical or physiologically active in the body.

\section{References}

Adcock, I.M., Caramori, G., 2001. Cross-talk between proinflamatory transcription factors and glucocorticoida. Immunol. Cell Biol. 79(4), 376-384.

Bagrov, A.Y., Shapiro, J.I., Fedorova, O.V., 2009. Endogenous cardiotonic steroids: physiology, pharmacology, and novel therapeutic targets. Pharmacol. Rev. 61(1), 9-38.

Bottcher, H., 1965. Miracle drugs, Zora, Zagreb.

Coassini, L., Poldini, L., 1988. Herbal remedies in the traditional medicine of the Venezia Giulia Region (North East Italy). J Ethnopharm. 22(3), 231-79.

Čučković, D., 1939. Prilog farmakognoškom istraživanju crnocrvenog kukurijeka (Helleborus atrirubens Waldst. et 
Kit.). Doktorska disertacija, Zagreb.

Dalakishvili, T.M., 1983. Fatty acidic composition of lipids from the roots and rhizomes of Helleborus caucasicus. Soobshch Akad Nauk Gruz SSR. 112(3), 565-568.

Deichmann, W.B., Henschler, D., Holmstedr, B., Keil, G., 1986. What is there that is not a poison? A study of the Third Defence by Paracelsus. Arch. Toxicol. 58, 207-213.

Dervendzi, V., 1986. Prirodni lekoviti I aromaticni surovini. Nasa kniga, Skopje.

Dilparić-Knežević, E., 1977. Bufadienolidi I bazične supstancije u vrstama roda Helleborus. Magistarska teza, Zagreb.

Frohne, D., Pfänder, H.J., 2005. Poisonous Plants, A Handbook for Doctors, Pharmacists, Toxicologists, Biologists and Veterinarians, Second ed. Manson Publishing Ltd.

Gajić, M., 1992. Fam. Ranunculaceae A. L. Juss. In: Sarić RM I ost., Flora Srbije 1, Srpska akademija nauka I umetnosti. Odeljenje prirodno matematičkih nauka. Beograd, 274280.

Gligič, V., 1953. Etimološki botanički rečnik. "Veselin Masleša", Sarajevo.

Gorunovic, S.M., Lukic, P., 2001. Farmakognozija. Farmaceutski fakultet Univerziteta u Beograd, Beograd.

Grossarth-Maticek, R., Kiene, H., Baumgartner, S.M., Ziegler, R., 2001. Use of Iscador, an extract of European mistletoe (Viscum album), in cancer treatment: prospective nonrandomized and randomized matched-pair studies nested within a cohort study. Altern. Ther. Health Med. 7(3), 57-78.

Hajrulai, Z., 2001. Efektot na ekstraktot na Helleborus odorus vrz proteinskiot status kaj jagninjata. Doktorska disertacija, „Veterinaren fakultet”, Skopje.

Karrer, W., 1943. Über Hellebrin, ein krystallisiertes Glykosid aus Radix Hellebori nigri. Helv. Chim. Acta 26, 13531367.

Kißmer, B., Wichtl, M., 1986. Bufadienolide aus Samen von Helleborus odorus. Planta Med. 2, 152-153.

Kolesnikov, D.G., Tropp, M.I., 1952. Cardiac glycosides from root of Helleborus. Med. Prom. SSSR. 6(5), 17-20.

Kovacevic, N., 2000. Osnovi Farmakognozije. Licno izdanje, Beograd.

Micevski, K., 1985. Flora na SR Makedonija. Makedonska akademija na nauki I umetnost, Skopje.

Mulet, L., 1991. Estudio Ethnobotánico de la Provincia de Castellón, Diputación de Castellón, Castellón, Spain, 596.

Pěnčík, A., Rolčík, J., Novák, O., Magnus, V., Barták, P., Buchtík, R., Salopek-Sondi, B., Strnad, M., 2009. Isolation of novel indole-3-acetic acid conjugates by immunoaffinity extraction. Talanta 80, 651-655. Available at: https://doi.org/10.1016/j.talanta.2009.07.043.

Plowden, C.C., 1970. A Manual of Plant Names. George Allen \& Unwin, London.

Puglisi, S., Speciale, A., Acquaviva, R., Ferlito, G., Ragusa, S., De Pasquale, R., Iauk, L., 2009. Antibacterial activity of Helleborus bocconei Ten. Subsp. Siculus root extracts. J. Ethnopharmacol. 125, 175-177. Available at: https://doi.org/10.1016/j.jep.2009.06.011.

Rosselli, S., Maggio, A., Formisano, C., Napolitano, F.,
Senatore, F., Spadaro, V., Bruno, M., 2007. Chemical composition and antibacterial activity of extracts of Helleborus bocconei Ten. Subsp. Intermedius. Nat. Prod. Commun. 2, 675- 679. Available at: https://doi.org/10.1177/1934578X0700200611.

Silic, C., 1987. Sumske zeljaste biljke. Svjetlost, Saraevo.

Steyn, P.S., Van Heerden, F.R., 1998. Bufadienolides of plant and animal origin. Nat. Prod. Reports. 15, 397-413. Available at: https://doi.org/10.1039/a815397y.

Souto, W.M., Mourão, J.S., Barboza, R.R., Alves, R.R., 2011-b. Parallels between zootherapeutic practices in ethnoveterinary and human complementary medicine in northeastern Brazil. J. Ethnopharmacol. 134(3), 753-767. Available at: https://doi.org/10.1016/j.jep.2011.01.041.

Spoerke, J.D.G., Smolinske, S.C., 1990. Toxicity of Houseplants. CRC Press: Boca Raton, FL, 37-39.

Sprung, C.L., Caralis, P.V., Marcial, E., Pierce, M., Gelbard, M.A., Long, W.M., Duncan, R.C., Tendler, M.D., Karpf, M., 1984. The effects of high-dose corticosteroids in patient with septic shock. A perspective, controlled study. N. Engl. J. Med. 311(18), 1137-1143.

Stefanović, O., 1962. Ispitivanje glucida Helleborus-a biohemijskom metodom. Acta Pharm. Jug. 12, 139-146.

Steinegger, E., Hänsel, R., 1972. Lehrbuch d. allgemeinen Pharmakognosie. Springer Verlag, Berlin - Heidelberg New York.

Stroman, F., Jakovlev, V., Metzenauer, P., Roth, E., Thiemer, K., 1984. The pharmacology of a new cardiosteroid, a partially synthetic derivative of the aglycone hellebrigenin (acrihellin). Arzneimittelforschung. 34(7), 769-779.

Tosevski, J., Stojkovski, V., Ulčar, I., 1999. Odreduvanje na 8emperature koeficient na svinjite so upotreba na ekstrakt od bilkata Helleborus odorus. Zbornik na trudovi, XXIV sredba "Fakultet - stopanstvo" '99, Skopje 7, 177- 189.

Tucakov, J., 1971. Healing with plants - phytotherapy. Culture, Beograd.

Tucakov, J., 1996. Lečenje biljem. Rad, Beograd.

Van Tellingen, C., 2007. Pliny's pharmacopoeia of the Roman treatment. Neth. Heart J. 15, 118-120. Available at: https://doi.org/10.1007/bf03085966.

Vitalini, S., Braca, A., Fico, G., 2011. Study on secondary metabolite content of Helleborus niger L. Leaves. Fitoterapia 82, 152-154. Available at: https://doi.org/10.1016/j.fitote.2010.08.012.

Wiart, C., 2006. Etnopharmacology of medicinal plants. Humana Press, New Jersey.

Wittmann, V., 2008. Glycoproteins: Occurrence and Significance, Glycoscience: Chemistry and Chemical Biology; Fraser-Reid, B.O., Tatsuta, K., Thiem, J., Eds. Springer, Berlin/Heidelberg.

Yang, J., Zhang, Y., Miao, F., Zhou, L., Sun, W., 2010. Two new bufadienolides from the rhizomes of Helleborus thibetanus Franch. Fitoterapia 81, 636-639. Available at: https://doi.org/10.1016/j.fitote.2010.03.009.

Živanov-Stakić, D., Mladenović, M., 1970-a. Novi postupak dobijanja triterpenskih saponozida biljke Helleborus odorus. Acta Pharm. Jug. 20, 183- 186. 


\title{
Резиме
}

\section{Етнофармаколошки и токсиколошки преглед на Helleborus sp.}

\author{
Анџела Брајановска, Билјана Бауер * \\ Фармачевтски факултет, Универзитет „Св. Кирил и Методиј”, Мајка Тереза 47, \\ 1000 Скопје, Република Македонија
}

Клучни зборови: Helleborus sp., фитомедицина, употреба во народната медицина, кардиотоник, токсичност, кукурек

Helleborus sp. се лековити растенија од фамилијата Ranunculaceae. Целта на овој труд е да се разгледа етнофармакологијата и токсичноста на различни видови кукурек која е фокусирана на детални истражувања на вредноста на фитохемикалиите, како фармаколошки атрибути на фитомедицинските билки. Податоците се изложени врз основа на активните компоненти. Исто така во овој труд е изложен хемискиот состав на коренот во целокупното дејство на дрогата како и важноста на различни видови кукурек во фармацијата. Различните видови кукурек покажуваат широк спектар на фармаколошко дејство како што е кардиотонично, имуностимулативно, антибактериско, антитуморно, диуретично и еметично дејство. Helleborus odorus Waldst. et Kit. е богат со секундарни метаболити како што се буфаденолиди, флавоноиди, фенолни хетерозиди. Со ова истражување е заклучено дека ова растение има големо значење и голема примена во фомулација на фармацевтски дозирани форми. 
